Article

\title{
Synthesis of Ethano-Bridged Diazapolycenes as Potential Precursors for Diazapolycenes and Their Properties
}

\author{
Moinul Karim and Yurngdong Jahng * \\ Department of Pharmacy, College of Pharmacy, Yeungnam University, Gyeongsan 38541, Korea; \\ mukulnmr@gmail.com \\ * Correspondence: ydjahng@ynu.ac.kr; Tel.: +82-53-810-2821 \\ Academic Editor: J.A.A.W. Elemans \\ Received: 4 February 2016 ; Accepted: 19 March 2016 ; Published: 25 March 2016
}

\begin{abstract}
A series of ethanodiazapolycenes were prepared in $87 \%-89 \%$ yields by Friedländer reactions of three $o$-aminoarenecarbaldehydes with bicyclo[2.2.2]octane-2,5-dione and their spectral, thermal, and structural properties were studied. Subsequent attempts to convert them to diazapolycenes have proved unsuccessful.
\end{abstract}

Keywords: azapentacene; diazapolycene; 6,13-dihydro-6,13-ethano-5,12-diazapentacene; 7,16-dihydro-7,16-ethano-6,15-diazaheptacene; 8,19-dihydro-8,19-ethano-7,18-diazanonacene

\section{Introduction}

The polycenes, represented by pentacene (1a) have long been of interest in the area of semiconductors with potential applications in organic thin-film transistors (OTHFTs) [1-3], and organic light-emitting diodes [4]. In order to overcome the major drawbacks of pentacene such as its insolubility at room temperature and rapid degradation [5], continuous efforts have been pursued to prepare soluble precursors that can be thermally converted to pentacene [6], the introduction of substituent(s) on the basic skeleton [7-9], and substitution of the benzene moiety by isosteric aromatics such as thiophene (compound 2) [10], and pyridine (compounds 3 [11] and 4 ([12]) (Figure 1).

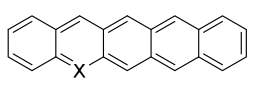

1a $(X=$ pentacene $)$ $\mathbf{b}(\mathrm{X}=\mathrm{N}, 5$-azapentacene $)$

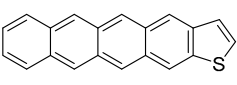

2

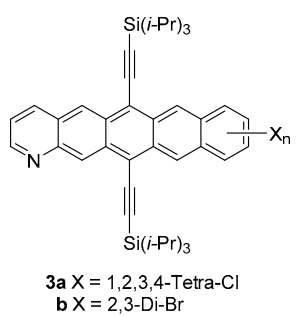

bX $=2,3-\mathrm{Di}-\mathrm{B}$

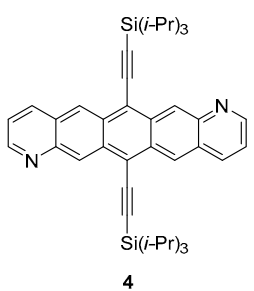

Figure 1. Pentacene and its isosteres.

Theoretically, introduction of a nitrogen atom significantly decreases the frontier molecular orbital energy and hence improves the stability in air and to light [13]. This has led to the synthesis of large numbers of $N$-heteroacenes with pyrazine units in recent years [14,15]. The 1-azapentacenes with bis(triisopropylsilyl)ethynyl groups such as $\mathbf{3}$ in fact showed potential for high-performance organic semiconductors with superior structure-activity characteristics that the corresponding pentacene derivative, 6,13-bis[(triisopropylsilyl)ethynyl]pentacene [16]. Recently, we reported a synthesis and the properties of 5-azapentacene (1b, Figure 1) [17], which might open a new vista for the studies on azapolycenes. As part of our ongoing studies on azaaromatics [17-19], we describe herein a preparation 
of ethano-bridged diazapolycenes as dimeric diazapolycenes and our attempts at the preparation of the corresponding diazapolycenes.

\section{Results and Discussions}

\subsection{Synthesis}

Synthesis of the compounds was straightforward as shown in Scheme 1. The Friedländer reactions of $o$-aminoarenecarbaldehydes 5 with diketone $\mathbf{6}$ afforded the corresponding ethano-bridged diazapolycenes 7 in $87 \%-89 \%$ yields. The prerequisite starting 2-aminobenzaldehyde (1a) [20], 3-aminonaphthalene-2-carbaldehyde (5b) [21], 3-aminoanthracene-2-carbaldehyde (5c) [17], and bicyclo[2.2.2] octane-2,5-dione (6) [22] were prepared employing the corresponding previously reported methods.

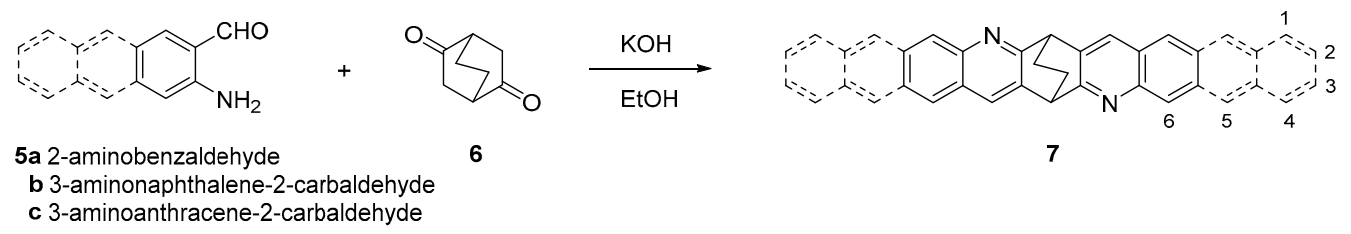

Scheme 1. Synthesis of ethano-bridged diazapolycenes.

\subsection{Attempts to Convert $\mathbf{7}$ to the Corresponding Diazapolycenes $\mathbf{8}$}

Catalytic dehydrogenation and/or dealkylation [23-26] and vacuum pyrolysis [27-31] of cyclohexenes have been commonly employed to build up benzene rings, in which the former proceeds via elimination of alkyl substituent(s) and the latter via retro-Diels-Alder reaction. However, all attempts, including catalytic dehydrogenation $\left(10 \% \mathrm{Pd} / \mathrm{C}\right.$ in nitrobenzene at $200{ }^{\circ} \mathrm{C}$ for $\left.8 \mathrm{~h}\right)$ and vacuum pyrolysis $\left(0.02 \mathrm{mmHg}, 600{ }^{\circ} \mathrm{C}, 45-60 \mathrm{~min}\right)$ of the compounds 7 leading to the corresponding diazapolycenes $\mathbf{8}$ have been as yet unsuccessful (Scheme 2). It should be noted that vacuum pyrolysis of $7 \mathbf{a}, \mathbf{b}$ resulted in sublimation of the compounds which remain unchanged, while $7 \mathbf{c}$ decomposed.

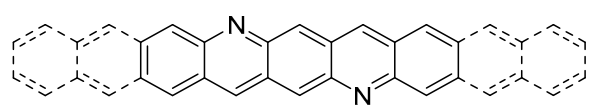

8

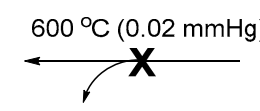

$\mathrm{CH}_{2}=\mathrm{CH}_{2}$

(retro Diels-Alder)

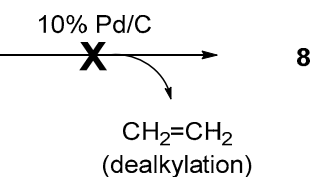

(dealkylation)

Scheme 2. Synthesis of diazapolycenes.

\subsection{Spectroscopic Properties}

${ }^{1} \mathrm{H}-\mathrm{NMR}$ spectral data of selected protons are summarized in Table 1. All the proton resonances were assigned by comparison with previously reported data for related compounds such as quinoline [32], benzo[g] quinoline [33], and 5-azapentacene [17] and by double quantum H-H COSY experiments. The resonances of $\mathrm{H} 4$ and the proton at the peri-position in the most of the polypyridines and polyquinolines, are characteristic and have been used as a diagnostic probe for understanding the structural information. The resonances of $\mathrm{H} 4$ were shifted downfield by $0.73 \mathrm{ppm}$ for $\mathbf{7 b}$ compared to $7 \mathbf{a}$, and $0.40 \mathrm{ppm}$ for $\mathbf{7 c}$ compared to $\mathbf{7 b}$. These values are comparable to those of related compounds such as quinoline, benzo[g]quinoline, and 5-azapentacene, reflecting increased delocalization of $\pi$-orbitals in the aromatic systems as the number of aromatic rings increases. Similar trends were also observed for the proton at the peri-position. It should be noted that the ethane bridge protons of $7 \mathbf{a}$ resonated at $\delta 2.03$ as a singlet, while those of $7 \mathbf{b}$ and $7 \mathbf{c}$ were multiplets in the range of $\delta 2.25-2.10$ and $\delta 2.27-2.23$, respectively, reflecting the fact these bridges are rigid at room temperature on the NMR time scale. 
Table 1. ${ }^{1} \mathrm{H}-\mathrm{NMR}$ chemical shifts and coupling constants of selected protons.

\begin{tabular}{|c|c|c|c|}
\hline Compounds & H4 & $\mathrm{H}$ at Peri-Position & $-\mathrm{CH}_{2} \mathrm{CH}_{2}-$ \\
\hline Quinoline ${ }^{(a)}$ & $8.00\left({ }^{3} J=8.3,^{4} J=1.1 \mathrm{~Hz}\right)$ & $8.05\left({ }^{3} J=8.2,{ }^{4} J=1.6 \mathrm{~Hz}\right)$ & \\
\hline Benzo[olauinoline & $8.58\left({ }^{3} J=8.5,{ }^{4} J=1 \mathrm{~Hz}\right)^{(b)}$ & $8.76(\mathrm{~s})^{(\mathrm{b})}$ & \\
\hline Benzo[g]quinoline & $8.31\left({ }^{3} J=8.5 \mathrm{~Hz}\right)^{(\mathrm{c})}$ & $8.70(\mathrm{~s})^{(\mathrm{c})}$ & \\
\hline Naphtho[2,3-g]quinoline ${ }^{(\mathrm{d})}$ & $8.50\left({ }^{3} J=7.5,{ }^{4} J=1.5 \mathrm{~Hz}\right)$ & $8.87(\mathrm{~s})$ & \\
\hline 5-Azapentacene ${ }^{(\mathrm{e})}$ & $9.12(\mathrm{~s})$ & $9.26(\mathrm{~s})$ & \\
\hline $7 a$ & $7.60(\mathrm{~s})$ & $8.01\left({ }^{3} J=8.3,{ }^{4} J=1.2 \mathrm{~Hz}\right)$ & $2.03(\mathrm{~s})$ \\
\hline $7 \mathrm{~b}$ & $8.33(\mathrm{~s})$ & $8.59(\mathrm{~s})$ & $2.25-2.10(\mathrm{~m})$ \\
\hline $7 \mathrm{c}$ & $8.73(\mathrm{~s})$ & $8.85(\mathrm{~s})$ & $2.27-2.23(\mathrm{~m})$ \\
\hline
\end{tabular}

(a) Ref. [32]; (b) Taken from $250 \mathrm{MHz}^{1} \mathrm{H}-\mathrm{NMR}$ in $\mathrm{CDCl}_{3}$; ${ }^{\text {(c) }}$ Ref [33]; ${ }^{\text {(d) }}$ Taken from the ChemDraw ${ }^{\circledR}$ computer program from CambridgeSoft; ${ }^{(e)}$ Ref [17].

UV absorption spectra of 7 were obtained in $\mathrm{EtOH}\left(1.0 \times 10^{-6} \mathrm{M}\right)$ (Figure 2) and the absorption maxima and extinction coefficients are summarized in Table 2. The absorption bands in the 245-303 and 331-400 $\mathrm{nm}$ regions correspond quite closely to the $\pi-\pi^{*}$ absorptions. The absorption maxima for the more linear compounds $(\mathbf{7 a} v s .7 \mathbf{b}, 7 \mathbf{b} v s .7 \mathbf{c}$ ) appear shifted towards longer wavelengths (see Figure 2). These data are consistent with an electronic transition state in which the energy of the receptor $\pi^{*}$ orbital is lowered by the increasing delocalization which would be found for the more conjugated and linear systems. The electronic spectrum of the most linear compound $7 \mathrm{c}$ showed $\pi-\pi^{*}$ absorption bands at 303 and $325 \mathrm{~nm}$ which are red-shifted compared to the parent compound $7 \mathbf{a}$ by 58 and $80 \mathrm{~nm}$, with little effect on the intensity of the absorption compared to 7a. It should be noted that benzoannulation led an additional absorption band in the region of 350-408 nm, of which 7c showed the most intense and bathochromic shifted absorption due to the additional benzene ring.

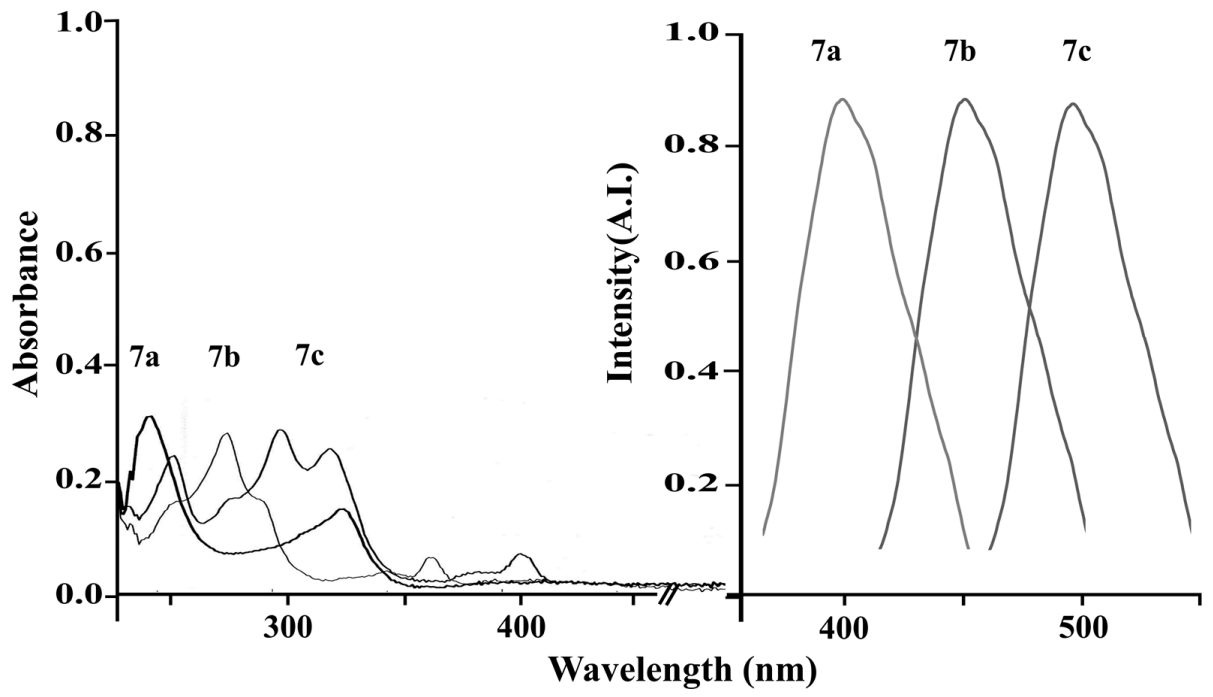

Figure 2. UV absorption and photoluminescence (PL) spectra of $7 \mathbf{a}, 7 \mathbf{b}$, and $7 \mathbf{c}$ in EtOH $\left(1 \times 10^{-6} \mathrm{M}\right)$ at $298 \mathrm{~K}$.

The photoluminescence (PL) of the compounds was studied in EtOH $\left(1 \times 10^{-5} \mathrm{~mol} / \mathrm{L}\right)$ at room temperature (Figure 2) and are summarized in Table 2. Excitation of the absorbances at 245, 280, and $303 \mathrm{~nm}$ for $\mathbf{7 a}, \mathbf{7 b}$, and $\mathbf{7 c}$, respectively, showed emissions at 400, 465, and $500 \mathrm{~nm}$. The observed emission wavelength is somewhat dependent on the nature of the conjugated system: The most extended compound $7 \mathrm{c}$ showed a green light emission at $500 \mathrm{~nm}$ while $7 \mathbf{a}$ showed a purple light emission at $400 \mathrm{~nm}$. The quantum yields were determined by a previously reported method $[34,35]$ employing quinine sulfate as a standard to give values of $0.38,0.54$, and 0.58 for $7 \mathbf{a}, 7 \mathbf{b}$, and $7 \mathbf{c}$, respectively. 
Table 2. UV absorption and FL data of compounds $7 \mathbf{a}, 7 \mathbf{b}$, and $7 \mathrm{c}$.

\begin{tabular}{ccccc}
\hline Compd. & $\lambda[\mathbf{n m}(\log \varepsilon)]$ & $\lambda_{\text {excit }}$ & $\lambda_{\text {emit }}$ & Quantum Yield $^{(a)}$ \\
\hline 7a & $245(5.49) 331(5.18)$ & 245 & 400 & 0.38 \\
$7 \mathbf{b}$ & $256(5.20, \mathrm{sh}) 280(5.46) 297(5.20$, sh) 350 (4.61) 370 (4.81) & 280 & 465 & 0.54 \\
$7 \mathbf{c}$ & $257(5.39) 303(5.46) 325(5.41) 408(4.85)$ & 303 & 500 & 0.58 \\
\hline
\end{tabular}

(a) Values were calculated from the equation given in Ref. [34,35] using quinine sulfate as a reference.

\subsection{Structural and Thermal Properties}

The crystallinity of the compounds prepared was analyzed by X-ray diffraction (XRD) and the corresponding X-ray diffractograms are shown in Figure 3. The diffractograms of compounds 7a and 7b showed distinctive peaks, indicating their crystalline nature. Compounds 7a, of which the X-ray crystal structure has been reported [36], and $\mathbf{7 b}$ have more crystalline character comparing to $7 \mathbf{c}$. The crystallite sizes of $\mathbf{7 a}$ and $\mathbf{7 b}$ were calculated by employing Scherrer's equation, $D_{\mathrm{p}}=0.93 \lambda / L \cos \theta$ [37], where $D_{\mathrm{p}}$ is the averaged particle size of the crystallites, $\lambda$ is the incident wavelength (1.54056 $\AA$ ), $\theta$ is the Bragg angle and $L$ is the diffracted full width at half maximum (in radians) caused by crystallization to give 6.89 and $10.54 \mathrm{~nm}$ for $7 \mathbf{a}$ and $7 \mathbf{b}$, respectively.

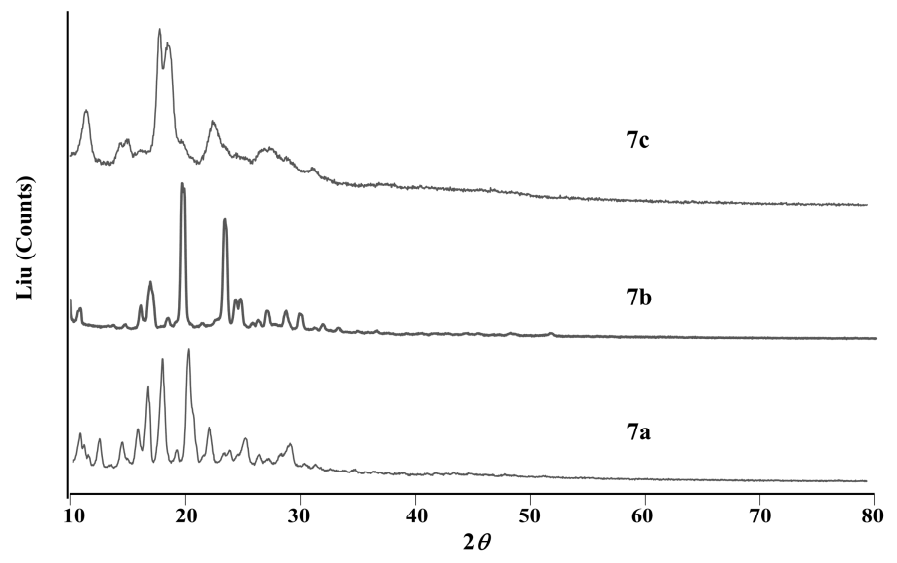

Figure 3. X-ray diffractograms of compounds $7 \mathbf{a}, 7 \mathbf{b}$, and $7 \mathbf{c}$ in powder state.

The thermal behaviors of the compounds were analyzed by differential scanning calorimetry (DSC). All the compounds showed a single sharp endothermic peak at the melting transition temperature $\left(T_{\mathrm{m}}\right)$ of $287.3,397.35$, and $409.78^{\circ} \mathrm{C}$, respectively. However only compound 7 a showed sharp exothermic peaks as a crystallization temperature (Tc) at $202.74{ }^{\circ} \mathrm{C}$ (data not shown). It should be noted that none of the compounds showed a glass transition temperature $\left(T_{\mathrm{g}}\right)$.

\section{Experimental Section}

\subsection{General Information}

Melting points were determined using a Fischer-Jones melting points apparatus (Fischer Scientific, Grand Island, NY, USA) and are not corrected. UV spectra were recorded on a V550 spectrophotometer (JASCO, Oklahoma City, OK, USA). NMR spectra were obtained using a Bruker-250 spectrometer (Fällanden, Switzerland) or VNS600 FT-NMR (Varian, Australia) operating at $250 \mathrm{MHz}$ or $600 \mathrm{MHz}$ for $1 \mathrm{H}-\mathrm{NMR}$ and $62.5 \mathrm{MHz}$ or $150 \mathrm{MHz}$ for 13C-NMR and are reported as parts per million (ppm) from the internal standard TMS. Chemicals and solvents were commercial reagent grade and used without further purification. Electrospray ionization (ESI) mass spectrometry (MS) experiments were performed on a LCQ advantage-trap mass spectrometer (Thermo Finnigan, San Jose, CA, USA). Elemental analyses were taken on a Hewlett-Packard Model 185B elemental analyzer (Hewlett Packard, 
Littleton, MA, USA). XRD analysis was performed by X-ray diffractometry (MPD for bulk, PANalytical, Wesybrough, MA, USA) with nickel-filtered $\mathrm{CuK} \alpha$ radiation $(30 \mathrm{kV}, 30 \mathrm{~mA})$ at $2 \theta$ angles from $10^{\circ}$ to $90^{\circ}$, a scan speed of $10^{\circ} / \mathrm{min}$ and a time constant of $1 \mathrm{~s}$. Thermal behaviors of the compounds were analyzed using differential scanning calorimeter (DSC Q200, TA Instrument, Wilminton, NJ, USA) with 1 2 $\mathrm{mg}$ of sample sealed in alumina in the range of $40-385^{\circ} \mathrm{C}$ increasing temperature in a rate of $10^{\circ} \mathrm{C} / \mathrm{min}$. An empty pan was used as a reference, and the DSC baseline, temperature, and enthalpy were calibrated. High and low resolution FAB-MS data were obtained on a JMS-700 instrument (JEOL, Peabody, MA, USA).

\subsection{Synthesis and Characterization of the Products}

\section{6,13-Dihydro-6,13-ethano-5,12-diazapentacene (7a)}

To a mixture of 2-aminobenzaldehyde (5a, $0.59 \mathrm{~g}, 4.9 \mathrm{mmol})$ and bicyclo[2.2.2]octane-2,5-dione $(6,0.30 \mathrm{~g}, 2.18 \mathrm{mmol})$ in $\mathrm{EtOH}(15 \mathrm{~mL})$ was added $2 \mathrm{M} \mathrm{KOH}$ in $\mathrm{EtOH}(1 \mathrm{~mL})$. The resulting mixture was refluxed for $8 \mathrm{~h}$ to form a precipitate which was collected and washed with EtOH to give pale yellow needles $\left(0.60 \mathrm{~g}, 88 \%\right.$ ): $\mathrm{mp} 297-298^{\circ} \mathrm{C}$ (lit. [36] mp 284-285 ${ }^{\circ} \mathrm{C}$ ). Spectral data were identical to those reported previously [36]. ${ }^{1} \mathrm{H}-\mathrm{NMR}\left(\mathrm{CDCl}_{3}, 250 \mathrm{MHz}\right) \delta 8.33$ (s, 2H, H7 and H14), 8.01 (d, $J=8.3 \mathrm{~Hz}, 2 \mathrm{H}, \mathrm{H} 4$ and $\mathrm{H} 11), 7.95(\mathrm{~d}, J=7.9 \mathrm{~Hz}, 2 \mathrm{H}, \mathrm{H} 1$ and $\mathrm{H} 8), 7.73(\mathrm{td}, J=8.3,1.0 \mathrm{~Hz}, \mathrm{H} 3$ and H10), $7.60(\mathrm{td}, J=8.0,1.0 \mathrm{~Hz}, \mathrm{H} 2$ and $\mathrm{H} 9), 4.80\left(\mathrm{~s}, 2 \mathrm{H}, \mathrm{H} 6\right.$ and H13), $2.03(\mathrm{~s}, 4 \mathrm{H}) .{ }^{13} \mathrm{C}-\mathrm{NMR}\left(62.5 \mathrm{MHz}, \mathrm{CDCl}_{3}\right)$ $\delta 25.5,45.8,126.3,127.3,128.0,128.6,129.5,130.3,134.2,146.3,163.4$.

\section{7,16-Dihydro-7,16-ethanobenzo[b]benzo[6,7]quinolino[3,2-i]acridine (7,16-dihydro-7,16-ethano-6,15-diaza-heptacene, 7b)}

To a mixture of 3-aminonaphthalene-2-carbaldehyde (5b, $280 \mathrm{mg}, 1.63 \mathrm{mmol})$ and bicyclo[2.2.2] octane-2,5-dione (6, $90 \mathrm{mg}, 0.65 \mathrm{mmol})$ in $\mathrm{EtOH}(10 \mathrm{~mL})$ was added $2 \mathrm{M} \mathrm{KOH}$ in EtOH $(1 \mathrm{~mL})$. The resulting reaction mixture was refluxed for $8 \mathrm{~h}$. Evaporation of the solvent provided pale yellow crystalline solids (236 mg, 89\%), which was purified by flash column chromatography on silica eluting with EtOAc to give the desired product as pale yellow needles: mp $397.35{ }^{\circ} \mathrm{C}$ (DSC). ${ }^{1} \mathrm{H}-\mathrm{NMR}$ $\left(\mathrm{CDCl}_{3}, 250 \mathrm{MHz}\right) \delta 8.60$ (s, 2H, H5 and H14), 8.33 (s, 2H, H8 and H17), 8.19 (s, 2H, H9 and H18), 8.03 (overlapped dd, 4H, J = 7.8, 2.8 Hz, H1, H4, H10, H13), 7.50-7.46 (m, 4H, H2, H3, H11, H12), 4.77 (s, 2H, H7 and H16), 2.25-2.10 (m, 4H). ${ }^{13} \mathrm{C}-\mathrm{NMR}\left(\mathrm{CDCl}_{3}, 62.5 \mathrm{MHz}\right) \delta 163.9,143.6,133.8,133.1,131.8$, 130.6, 128.6, 128.2, 126.7, 126.6, 126.4, 126.3, 126.1, 46.7, 25.5. MS (ESI) calcd for $\mathrm{C}_{30} \mathrm{H}_{20} \mathrm{~N}_{2}[\mathrm{M}+\mathrm{H}]^{+} 409$, found 409. HR-FAB-MS (m/z): [M+] calcd for $\mathrm{C}_{30} \mathrm{H}_{20} \mathrm{~N}_{2}, 408.16265$; found, 408.1629. Anal. calcd for $\mathrm{C}_{30} \mathrm{H}_{20} \mathrm{~N}_{2} \mathrm{C}, 88.21 ; \mathrm{H}, 4.94 ; \mathrm{N}, 6.86$. Found $\mathrm{C}, 88.39 ; \mathrm{H}, 4.93$.

8,19-Dihydro-8,19-ethanonaphtho[2,3-b]naphtho[2', 3':6,7]quinolino[3,2-i]acridine (8,19-dihydro-8,19-ethano-7,18-diazanonacene, 7c)

A mixture of 3-aminoanthracene-2-carbaldehyde (5c, $360 \mathrm{mg}, 1.63 \mathrm{mmol}, 2.5$ equiv), bicyclo[2.2.2] octane-2,5-dione $(6,90 \mathrm{mg}, 0.65 \mathrm{mmol})$, and $2 \mathrm{M} \mathrm{KOH}$ in EtOH (1 mL) in EtOH (10 mL) was refluxed for $8 \mathrm{~h}$. Work-up as described above for 7a afforded a pale crystalline solid (291 mg, $88 \%$ ) as a desired product which was flash-chromatographed on silica eluting with EtOAc. The later fractions afforded yellow solid: $\mathrm{mp} 409.78^{\circ} \mathrm{C}$ (DSC) (dec). ${ }^{1} \mathrm{H}-\mathrm{NMR}\left(\mathrm{CDCl}_{3}, 250 \mathrm{MHz}\right) \delta 8.85(\mathrm{~s}, 2 \mathrm{H}$, $\mathrm{H6}$ and H17), 8.73 (s, 2H, H9 and H20), 8.68 (s, 2H, H10 and H21), 8.59 (s, 2H, H5 and H16), 8.21 (s, 2H, $\mathrm{H} 11$ and H22), 8.03 (dd, 2H, $J=7.8,1.5 \mathrm{~Hz}, \mathrm{H} 4, \mathrm{H} 14), 8.00$ (dd, 2H, J = 7.8, $1.5 \mathrm{~Hz}, \mathrm{H} 1, \mathrm{H} 12), 7.45-7.41$ (m, 4H, H2, H3, H13, H14), 4.76 (s, 2H, H8 and H18), 2.27-2.23 (m, 4H). A ${ }^{13} \mathrm{C}-\mathrm{NMR}$ spectrum could not be recorded due to the low solubility in common NMR solvents. MS (ESI) calcd for $\mathrm{C}_{38} \mathrm{H}_{25} \mathrm{~N}_{2}$ $[\mathrm{M}+\mathrm{H}]^{+}$509, found 509. HR-FAB-MS $(\mathrm{m} / z)$ : $\left[\mathrm{M}^{+}\right]$calcd for $\mathrm{C}_{38} \mathrm{H}_{24} \mathrm{~N}_{2}, 508.19395$; found, 508.1641 . Anal. calcd for $\mathrm{C}_{38} \mathrm{H}_{24} \mathrm{~N}_{2}-1.5 \mathrm{H}_{2} \mathrm{O}$ C, 85.21; H, 5.08; N, 5.23. Found C, 85.26; H, 5.07; N, 5.21. 


\subsection{Attempted Synthesis of Diazapolycenes $\mathbf{8}$}

Method A: A mixture of $7(1.0 \mathrm{mmol})$ and $10 \% \mathrm{Pd} / \mathrm{C}(100 \mathrm{mg})$ in nitrobenzene $(10 \mathrm{~mL})$ was heated $200{ }^{\circ} \mathrm{C}$ for $8 \mathrm{~h}$. After cooling the reaction mixture to room temperature, reaction mixture was filtered through Celite ${ }^{\circledR}$. Work up as usual afforded a pale yellow solid, which turned out the starting material based on TLC as well as ${ }^{1} \mathrm{H}-\mathrm{NMR}$.

Method B: The vacuum pyrolysis $\left(0.02 \mathrm{mmHg}, 600^{\circ} \mathrm{C}, 45-60 \mathrm{~min}\right)$ of the compound 7 (1.0 mmol) did not lead to the corresponding diazapolycenes 8 but instead sublimation of the product occurred for $\mathbf{7 a}, \mathbf{b}$, while $\mathbf{7 c}$ was decomposed at $409^{\circ} \mathrm{C}$ without sublimation.

\subsection{Measurement of Quantum Yield ( $\Phi)$}

The quantum yield of the compounds prepared was measured by using a quinine sulfate solution (in $0.1 \mathrm{M} \mathrm{H}_{2} \mathrm{SO}_{4}$, literature quantum yield 0.577 at $360 \mathrm{~nm}[34,35]$ ) as the standard and calculated with the equation of $\Phi=\Phi_{\mathrm{R}} \times\left(\mathrm{I} / \mathrm{I}_{\mathrm{R}}\right) \times(\mathrm{OD} / \mathrm{OD}) \times\left(n^{2} / n_{\mathrm{R}}{ }^{2}\right)$, where $\Phi$ is the quantum yield, $\mathrm{I}$ is the measured integrated emission intensity, $n$ is the refractive index, OD is the optical density and the subscript $R$ refers to the quinine sulfate.

\section{Conclusions}

The Friedländer reactions of three $o$-aminoarenecarbaldehydes, namely 2-aminobenzaldehyde, 3-aminonaphthalene-2-carbaldehyde and 3-aminoanthracene-2-carbaldehyde, with bicyclo[2.2.2]octane-2,5-dione yielded a series of ethanodiazapolycenes as dimeric azapolycenes in $87 \%-89 \%$ yields and their spectral, thermal, and structural properties were studied. All attempts to further convert the products into diazapolycenes by retro-Diels-Alder reaction or vacuum pyrolysis were not successful.

Acknowledgments: Financial support from Yeungnam University (213A380193) is gratefully appreciated.

Author Contributions: MK performed synthesis, characterization, gathering spectral data of the compounds and participated in manuscript writing. YJ planned the experiments, supervised, and wrote the paper.

Conflicts of Interest: The authors declare no conflict of interest.

\section{References}

1. Brown, A.R.; Pomp, A.; Hart, C.M.; de Leeuw, D.M. Logic gates made from polymer transistors and their use in ring oscillators. Science 1995, 270, 972-974. [CrossRef]

2. Dimitrakopoulos, C.D.; Malenfant, P.R.L. Organic thin film transistors for large area electronics. Adv. Mater. 2002, 14, 99-117. [CrossRef]

3. Kleemann, H.; Gutierrez, R.; Avdoshenko, S.; Cuniberti, G.; Leo, K.; Luessem, B. Reverse breakdown behavior in organic pin-diodes comprising C60 and pentacene: Experiment and theory. Org. Electron. 2013, 14, 193-199. [CrossRef]

4. Wolak, M.A.; Jang, B.; Palilis, L.C.; Kafafi, Z.H. Functionalized pentacene derivatives for use as red emitters in organic light-emitting diodes. J. Phys. Chem. B 2004, 108, 5492-5499. [CrossRef]

5. Etienne, A.; Beauvois, C. Photooxidation of 6,13-diphenylpentacene and 5,7,12,14-tetraphenylpentacene. Compt. Rend. 1954, 239, 64-66.

6. Afzali, A.; Kagan, C.R.; Traub, G.P. N-Sulfinylcarbamate-pentacene adduct: A novel pentacene precursor soluble in alcohols. Synth. Met. 2005, 155, 490-494. [CrossRef]

7. Allen, C.F.H.; Bell, A. Action of Grignard reagents on certain pentacenequinones, 6,13-diphenylpentacene. J. Am. Chem. Soc. 1942, 64, 1253-1260. [CrossRef]

8. Kaur, I.; Jia, W.J.; Kopreski, R.P.; Selvaprasah, S.; Dokmeci, M.R.; Pramanik, C.; McGruer, N.E.; Miller, G.P. Substituent effects in pentacenes: Gaining control over HOMO-LUMO gaps and photooxidative resistances. J. Am. Chem. Soc. 2008, 130, 16274-16286. [CrossRef] [PubMed]

9. Zhang, J.; Pawle, R.H.; Haas, T.E.; Thomas, S.W., III. Combining electronic and steric effects for highly stable unsymmetric pentacenes. Chem. Eur. J. 2014, 20, 5880-5884. [CrossRef] [PubMed] 
10. Kraft, U.; Anthony, J.E.; Ripaud, E.; Loth, M.A.; Weber, E.; Klauk, H. Low-voltage organic transistors based on tetraceno[2,3-b]thiophene: Contact resistance and air stability. Chem. Mater. 2015, 27, 998-1004. [CrossRef]

11. Song, C.-L.; Ma, C.-B.; Yang, F.; Zeng, W.-J.; Zhang, H.-L.; Gong, X. Synthesis of tetrachloro-azapentacene as an ambipolar organic semiconductor with high and balanced carrier mobilities. Org. Lett. 2011, 13, 2880-2883. [CrossRef] [PubMed]

12. Liu, Y.-Y.; Song, C.-L.; Zeng, W.-J.; Zhou, K.-G.; Shi, Z.-F.; Ma, C.-B.; Yang, F.; Zhang, H.-L.; Gong, X. High and balanced hole and electron mobilities from ambipolar thin-film transistors based on nitrogen-containing oligoacences. J. Am. Chem. Soc. 2010, 132, 16349-16351. [CrossRef] [PubMed]

13. Chen, Y.; Shen, L.; Li, X. Effects of heteroatoms of tetracene and pentacene derivatives on their stability and singlet fission. J. Phys. Chem. A 2014, 118, 5700-5708. [CrossRef] [PubMed]

14. Bunz, U.H.F. The larger linear N-heterocycles. Acc. Chem. Res. 2015, 48, 1676-1687. [CrossRef] [PubMed]

15. Zhang, J.; Wang, C.; Long, G.; Aratani, N.; Yamadab, H.; Zhang, Q. Fusing N-heterocene analogues into one "kinked" molecule with slipped two-dimensional ladder-like packing. Chem. Sci. 2016, 7, 1309-1313. [CrossRef]

16. Anthony, J.E.; Brooks, J.S.; Eaton, D.L.; Parkin, S.R. Functionalized pentacene: Improved electronic properties from control of solid-state order. J. Am. Chem. Soc. 2001, 123, 9482-9483. [CrossRef] [PubMed]

17. Jahng, Y.; Karim, M. Synthesis of 5-azapentacene by Friedländer reaction and its properties. Tetrahedron 2016, 72, 199-204. [CrossRef]

18. Karim, M.; Jahng, Y. Unusual product distribution from Friedländer reaction of di and triacetylbenzenes with 3-aminonaphthalene-2-carbaldehyde and properties of new benzo[ $g$ ]quinoline-derived aza-aromatics. Molecules 2014, 19, 12842-12851. [CrossRef] [PubMed]

19. Jahng, Y.; Rahman, A.F.M.M. Synthesis and properties of 2,2'-di(heteroaryl)-9,9'-spirobifluorenes. Bull. Chem. Soc. Jpn. 2010, 83, 672-677. [CrossRef]

20. Smith, L.I.; Opie, J.W. o-Aminobenzaldehyde. Org. Synth. Coll. 1955, 3, 56-58.

21. Taffarel, E.; Chirayil, S.; Thummel, R.P. Synthesis and properties of ligands based on benzo[g]quinoline. J. Org. Chem. 1994, 59, 823-828. [CrossRef]

22. Funel, J.-A.; Schmidt, G.; Abele, S. Design and scale-up of Diels-Alder reactions for the practical synthesis of 5-phenylbicyclo[2.2.2]oct-5-en-2-one. Org. Proc. Res. Dev. 2011, 15, 1420-1427. [CrossRef]

23. House, H.O. Modern Synthetic Reactions, 2nd ed.; W.A. Benjamin, Inc.: Readings, MA, USA, 1972; pp. $34-44$.

24. Kutz, W.M.; Corson, B.B. Dealkylation of dialkylbenzenes: Use of superatmospheric pressure and alumina-silica catalyst in presence of benzene. Ind. Eng. Chem. 1946, 38, 761-764. [CrossRef]

25. Linstead, R.P.; Thomas, S.L.S. Dehydrogenation. II. Elimination and migration of methyl groups from quaternary carbon atoms during catalytic dehydrogenation. J. Chem. Soc. 1940, 1127-1134. [CrossRef]

26. Csicsery, S.M.; Pines, H. Alumina: Catalyst and support. XVIII. Aromatization of 2,2-dimethyl-3-methyl$\mathrm{C}^{14}$-pentane over "non-acidic" chromia-alumina catalyst. Contribution to the mechanism of aromatization. J. Am. Chem. Soc. 1962, 84, 3939-3944. [CrossRef]

27. McNab, H. Chemistry without reagents: Synthetic applications of flash vacuum pyrolysis. Aldrichim. Acta 2004, 37, 19-26. [CrossRef]

28. Rickborn, B. The retro-Diels-Alder reaction, Part I: C-C dienophiles. Org. React. 1998, 52, 1-393.

29. Trahanovsky, W.S.; Swenson, K.E. Flash vacuum pyrolysis of 2,3-dialkyltetralins. J. Org. Chem. 1981, 46, 2984-2985. [CrossRef]

30. Alder, K.; Rickert, H.F. Zur Kenntnis der Dien-synthese. I. Über eine Methode der direkten Unterscheidung cyclischer Penta- und Hexa-diene. Ann. Chem. Pharm. 1936, 524, 180-189. [CrossRef]

31. Cadogan, J.I.G.; Hickson, C.L.; McNab, H. Short contact time reactions of large organic free radicals. Tetrahedron 1986, 42, 2135-2165. [CrossRef]

32. Pretsch, E.; Clerc, T.; Siebel, J.; Simon, W. Tables of Spectral Data for Structure Determination of Organic Compounds 13C-NMR 1H-NMR IR MS UV/VIS, 2nd ed.; Springer-Verlag: Berlin, Geramny, 1999; p. H335.

33. Krapcho, A.P.; Gilmor, T.P. General preparative route to benzo[g]quinolines (1-Azaanthracenes). J. Heterocycl. Chem. 1999, 36, 445-452. [CrossRef]

34. Lakowicz, J.P. Principles of Fluorescence Spectroscopy, 3rd ed.; Springer-Verlag: Berlin, Geramny, 2006; pp. 54-55.

35. Eastman, J.W. Quantitative spectrofluorimetry: The fluorescence quantum yield of quinine sulfate. Photochem. Photobiol. 1967, 6, 55-72. [CrossRef] 
36. Alshahateet, S.F.; Rahman, A.; Noman, M.M.; Bishop, R.; Craig, D.C.; Scudder, M.L. Interlocking molecular grid lattices involving weak assembly forces. CrystEngComm 2002, 4, 585-590. [CrossRef]

37. Patterson, A. The Scherrer formula for X-ray particle size determination. Phys. Rev. 1939, 10, 978-982. [CrossRef]

Sample Availability: Samples of the compounds 7 are available from the authors.

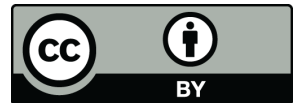

(C) 2016 by the authors; licensee MDPI, Basel, Switzerland. This article is an open access article distributed under the terms and conditions of the Creative Commons by Attribution (CC-BY) license (http:/ / creativecommons.org/licenses/by/4.0/). 